\title{
YOUNG PEOPLE'S ATTITUDES AND FINANCIAL BEHAVIOUR. EVIDENCE FROM ROMANIA
}

\author{
Alexandra DINU \\ University POLITEHNICA of Bucharest, Bucharest, Romania \\ dinualexandraluiza@gmail.com \\ Marian-Mircea STĂNESCU \\ University POLITEHNICA of Bucharest, Bucharest, Romania \\ mircea.stanescu97@gmail.com \\ Andreea BARBU \\ University POLITEHNICA of Bucharest, Bucharest, Romania \\ Barbu.andreeab@yahoo.com
}

\begin{abstract}
Nowadays, it is well known that money, through the means of obtaining and saving, has a major influence on the good functioning of the economy in society and implicitly in the process of its development. This influence has an impact on every individual in our society, on our decisions, choices, plans and preferences. At the same time, however, each participant in the economy of a state, whether it be individuals, companies, corporations or business partners, competes in the evolution of the economy through the type of management of the finances it adopts. In this regard, the present research aims to establish what is the young peoples' behavior (aged between 18 and 40) in terms of how to save money as well as the peoples' inclination to call a financial advisor for making decisions regarding the management of personal income and expenses. Therefore, with the help of survey type research, based on a questionnaire, the results of the study reveal an increased interest of Romanian young people in terms of the tendency to save money. It also highlights the awareness of the importance of financial knowledge in the process of saving money, as well as the tendency of respondents to constantly update this information, with the help of financial experts.
\end{abstract}

Keywords: financial behavior, saving money, finance, income management

\section{INTRODUCTION}

From all the assets that a person can own, the money is distinguished by their function as an intermediary for the exchange of goods and services. Representing a universal method of exchange, financial resources become a major advantage for the owner, offering the possibility of purchasing any type of service or product, which can be used to achieve their objectives, to increase the standard of living or even for hierarchical ascension in society (Goodhart, 1984). Besides people's desire to save money in order to 
secure financial resources for the future, to anticipate potential changes of the economy at the macro level and their implications or even to make a purchase in the future that at present cannot afford it, the main trigger for economic behaviour is, in fact, the association of two socio-economic factors.

These factors are represented by the level of income, but also by the satisfaction that the current financial situation gives. Financial satisfaction is a variable delimited by social comparison. So, the greater the difference in the financial situation compared to the reference person, in favour of those whose behaviour it is studied, the more it will have a greater tendency to save money. On the contrary, if the reference persons with whom the people are compared have a better financial situation, their tendency to save decreases because they try to reach the same standard of living. Therefore, the amount of savings is conditioned and then influenced both by the level of personal incomes, being necessary that they cover the usual expenses, as well as the positioning of the people towards the reference persons in order to establish the degree of personal financial satisfaction (Traut-Mattausch and Jonas, 2011).

The main objective of this study is to analyse the perception of young Romanians regarding the saving process, highlighting the trends in this regard. It is also important to establish the level to which they intend to save in the future (if the people surveyed have not saved up to this point), but also the desire of people to seek the help of a financial consultant for better management of their finances.

\section{LITERATURE REVIEW}

\subsection{SAVING-GENERAL NOTIONS}

The sharp decline in monetary policy interest rates marks the last decade in the developed part of the global economy. Various analyzes and debates, such as the one conducted by Silviu Cernea (2012) present structural causes in this regard: demography, productivity, globalization, financial crisis, overindebtedness, distribution or new technologies, which all had an impact on investment and savings. In recent years, some developments maintain, or increase uncertainties and exacerbate dilemmas for those who formulate monetary policies.

Closely correlated with people's income is the ability to pay bills on time, but also their desire to pay them during the period offered by the company. Credit freedom measures the extent to which consumers borrow to pay bills as well as the level of loans in relation to monthly income. Countries with relatively low Gross Domestic Product (GDP) tend to be higher on this pillar, due to a lower proportion of debt compared to revenue (INTRUM, 2019). Saving for the future measures the level of savings that consumers are willing to make each month along with the ability to save for an unforeseen event. Financial literacy is the indicator that measures the level of understanding of consumers regarding specific financial terms and calculations (INTRUM, 2019). 
The development stage of a country is also given by the saving rate of the population. Although this will not affect the long-term economic growth rate, it will influence the level of outputinhabitant, thus becoming an indicator of the change in the economic well-being of the region. In a country with a strong economy, the possibilities of placing the available economies of the population are extremely diversified, and the option for one instrument to the detriment of the other is given by the particularities of each economy, the financial culture of the population and not only. The economies are low, the market for saving instruments little developed, and the preference for placing the savings is related to the interest rate. The situation is not the same in a developing country (Constantin, 2012).

The preferences of people regarding the placement of savings are mainly oriented towards the following instruments: savings instruments offered by the state: government securities, treasury certificates, bonds, etc.; savings instruments offered by the private financial market: bank deposits, bonds, shares, etc. The option for one type of instrument to the detriment of another is given by the trust of the population in the institution in whose instruments it invests, by the maturity term, but first of all the individual behavior is influenced by the interest rate level. It is well known that trust in public power is considered unlimited because the state is not an entity that could be declared bankrupt (Călin, 2018).

\subsection{PROCESS OF SAVING MONEY IN ROMANIA}

The Romanian economy depends on what is happening in the European economic space, on the monetary policy of the European Central Bank (ECB). Monetary policy rates in our country and rates in the domestic money market are influenced by external monetary conditions. The budget execution in 2019 reveals a cash deficit at $4.4 \%$ of GDP, and an expected current account deficit exceeding $5 \%$ of GDP. Because of this major deviation of the budget, Romanian's economy is unique in the region (Dăianu, 2020).

It is very difficult for Romanian consumers to save money. After they pay their monthly bills, it is very difficult for them to manage financially, until the next salary. Romania's economy grew rapidly, registering a real GDP growth of $4.1 \%$ (EUROSTAT, 2018). However, despite the annual growth, the GDP per capita remains the lowest in this report, with a value of EUR 10,400 in 2018. Romanian consumers are on the last positions of the ranking when measuring the ability to pay bills. After paying the bills, $41 \%$ of those interviewed no longer have enough money to pay their monthly expenses. The negative rate of household savings explains Romania's poor performance when referring to future savings. According to Eurostat, in 2018, the gross saving rate registered in Romania reached a negative level of $-2.35 \%$, while $61 \%$ of consumers in Romania are not satisfied with the amount saved during each month (EUROSTAT, 2018). 
No one can predict the future, therefore, saving for unforeseen situations can help us to overcome certain moments. There are a lot of reasons why Romanian consumers save, but the average amount saved reaches a value of only $11 \%$ of salary. $45 \%$ of Romanians have as the main reason the unforeseen expenses, $40 \%$ the holidays, $34 \%$ save to secure their lifestyle and $21 \%$ for retirement. However, only $30 \%$ of respondents are confident that the income saved will provide them with a comfortable lifestyle at that time. Also, in the event of an unforeseen event, $72 \%$ of respondents cannot incur an expense higher than the equivalent of a salary without borrowing. The percentage of income savings, the maximum amounts available in case of an unforeseen incident and the gross saving rate ($2.35 \%$ ) place Romania on the 23 rd place out of 24 in the calculation of the indicator related to saving for the future (INTRUM, 2019). In order to be able to improve these figures in the shortest possible time, a "financial literacy" project should be introduced at a national level. Financial literacy is the ability to understand how money and the economy work: it comes down to a combination of skills and knowledge that helps to make effective decisions based on updated information. Improving financial literacy is a key factor, which helps the consumer to cope with future economic changes. Also, more financial knowledge has a positive impact on how consumers make decisions that can influence their financial well-being (Ciumara, 2006). In the European Consumer Payments Report (INTRUM, 2019), it is highlighted that $64 \%$ of Romanian respondents consider that they have a solid knowledge of the notions of financial education. Also, it can be observed the trend of learning more about the financial area, especially among men. The main areas of interest in the financial field are represented by stock market investments and pension fund planning. There is a high concern, among the majority of respondents, regarding the financial education transmitted to children, a fact also revealed by Romania's ranking above the European average in relation to the degree of financial literacy.

With the help of the recorded answers, the authors want to determine the level of financial education that young Romanians have currently. At the same time, the authors intend to find out the respondents' tendency to save money, as well as the elements that influence this decision, and the size of the savings related to their income. There are also studied the most used financial instruments for saving, and the extent to which young people are willing to seek the help of an authorized planner to achieve financial goals.

Thus, the objectives of this paper are:

01. Determining and analyzing the opinion of the respondents about the money-saving process.

O2. Determining the respondents' intention to save money in the future.

O3. Determining the respondents' intention to use the services of a financial adviser.

O4. Analyzing the issues related to the money-saving process. 


\section{METHODOLOGY}

To achieve the goals of the paper, a quantitative research was made, with the help of the survey, using it as a data collection tool the questionnaire. The questionnaire was developed using Google Forms, and was distributed through online social networks, such as Facebook and WhatsApp, but also via email. The sample consisted of respondents over the age of 18 who were asked to answer the 15 questions of the questionnaire. The data was collected over a period of one week, and at the end of the session, a total of 62 respondents were registered.

TABLE 1. THE VARIABLES USED TO CONSTRUCT THE QUESTIONNAIRE

\begin{tabular}{|c|c|c|c|}
\hline Factors & $\begin{array}{l}\text { Variable } \\
\text { code }\end{array}$ & Questions & Items \\
\hline \multirow{4}{*}{$\begin{array}{l}\text { The Opinion of } \\
\text { Saving }\end{array}$} & OS1 & Q1 & $\begin{array}{l}\text { Financial planning specialists argue that when we } \\
\text { receive any money the first payment must be made to } \\
\text { our financial security, therefore } 10 \% \text { of the income } \\
\text { must be saved monthly. Do you think this habit is } \\
\text { beneficial to your peace of mind? }\end{array}$ \\
\hline & OS2 & Q11 & $\begin{array}{l}\text { On a scale of } 1 \text { to } 5 \text {, how familiar are you with the } \\
\text { concept of saving money? }\end{array}$ \\
\hline & OS3 & Q3 & Have you saved money so far? \\
\hline & OS4 & Q5 & How and how often have you saved money so far? \\
\hline \multirow{2}{*}{$\begin{array}{l}\text { The Intention of } \\
\text { Saving in the } \\
\text { Future }\end{array}$} & ISF1 & Q2 & Would you like to save $10 \%$ of your monthly income? \\
\hline & ISF 2 & Q9 & $\begin{array}{l}\text { What amount would you allocate monthly and } \\
\text { constantly for savings? (the amount you can allocate } \\
\text { monthly without problems, in LEl) }\end{array}$ \\
\hline \multirow{2}{*}{$\begin{array}{l}\text { Intent to call a } \\
\text { Financial Advisor }\end{array}$} & IFA1 & Q10 & $\begin{array}{l}\text { Would you like to have a reliable person near you who } \\
\text { will guide you and offer you the most profitable and } \\
\text { reliable solutions for saving? }\end{array}$ \\
\hline & IFA2 & Q14 & $\begin{array}{l}\text { Would you like to discuss with an authorized planner } \\
\text { how you can achieve your goals? }\end{array}$ \\
\hline \multirow{3}{*}{$\begin{array}{l}\text { Saving in the } \\
\text { Present }\end{array}$} & SP1 & Q6 & $\begin{array}{l}\text { How long have you started saving money? } \\
\text { (MONTHS) }\end{array}$ \\
\hline & SP2 & Q7 & $\begin{array}{l}\text { What is the average amount of money you save } \\
\text { monthly (LEI)? }\end{array}$ \\
\hline & SP3 & Q8 & $\begin{array}{l}\text { How much money did you save on average so far? } \\
\text { (LEI) }\end{array}$ \\
\hline \multirow{4}{*}{$\begin{array}{l}\text { Demographic } \\
\text { Profile }\end{array}$} & DP1 & Q12 & Age \\
\hline & DP2 & Q13 & Occupation \\
\hline & DP3 & Q15 & Gender \\
\hline & DP4 & Q4 & Monthly income (LEI) \\
\hline
\end{tabular}

Source: Authors' own contribution

The questionnaire was structured in 5 sections (table 1): a first section aims to identify the respondents' opinion on saving (questions 1, 3, 5 and 11), the second section aims to identify the intention to save money in the future (questions 2 and 9), the third section deals with the intention of respondents to use 
the services of a financial adviser (questions 10 and 14), the fourth section deals with issues related to saving at the moment (questions 6, 7 and 8), while the last section contains the demographic profile (questions 4, 12, 13 and 15).

\subsection{RESULTS AND DISCUSSION}

To perform this study, the authors used several correlations analyzes using the statistical program from IBM: SPSS Statistics. One of the objectives of the study is to find out people's perceptions about saving behavior. The majority of the respondents are between 18 and 29 years old $(41.9 \%)$, while most of them are female $(54.8 \%)$. Table 2 shows the rest of the demographic data in terms of age, gender and occupation.

TABLE 2. DEMOGRAPHIC PROFILE OF RESPONDENTS

\begin{tabular}{|l|l|c|c|}
\hline \multirow{4}{*}{ Gender } & \multicolumn{1}{|c|}{ Characteristics } & Frequency & Percent (\%) \\
\hline \multirow{3}{*}{ Age } & Female & 34 & 54.8 \\
\cline { 2 - 4 } & Male & 28 & 45.2 \\
\hline \multirow{3}{*}{ Occupation } & $18-23$ years & 24 & 38.7 \\
\cline { 2 - 4 } & $24-29$ years & 26 & 41.9 \\
\cline { 2 - 4 } & $30-35$ years & 12 & 19.4 \\
\cline { 2 - 4 } & Entrepreneur & 9 & 14.6 \\
\cline { 2 - 4 } & Employee & 42 & 67.7 \\
\cline { 2 - 4 } & Student & 11 & 17.7 \\
\hline
\end{tabular}

Source: Authors' own contribution

To test the internal consistency of the items, the values of the Cronbach's Alpha coefficients were analyzed. As can be seen in Table 3 , the value of the Cronbach's Alpha coefficient is 0.644 , a value that is less than 0.7, as Hair et al (2007) recommends as the minimum accepted confidence level. At the same time, according to Fornell \& Larcker (1981), 0.644 maintains a good internal consistency of the items (according to them, the minimum accepted value is 0.5 ).

Table 3. Cronbach' Alpha coefficients

\begin{tabular}{|l|c|c|c|c|}
\hline Variables & $\begin{array}{c}\text { Scale Mean if } \\
\text { Item Deleted }\end{array}$ & $\begin{array}{c}\text { Corrected Item-Total } \\
\text { Correlation }\end{array}$ & $\begin{array}{c}\text { Cronbach' Alpha if } \\
\text { Item Deleted }\end{array}$ & $\begin{array}{c}\text { Cronbach's Alpha } \\
\text { Coefficient for } \\
\text { Saving in the } \\
\text { Present }\end{array}$ \\
\hline SP1 & 3.31 & .375 & .708 & \multirow{2}{*}{.644} \\
\hline SP2 & 3.03 & .697 & .236 & \\
\hline SP3 & 2.54 & .533 & .606 & \\
\hline
\end{tabular}

Source: Authors' own contribution

Regarding the perception of saving money (Table 4), $96.8 \%$ of respondents consider saving money to be beneficial for them. Also, $75.4 \%$ of respondents have saved money so far, the remaining $24.6 \%$ not doing so yet. 
TABLE 4. THE PERCEPTION OF SAVING

\begin{tabular}{|l|c|c|}
\hline \multicolumn{1}{|c|}{ Items } & $\begin{array}{c}\text { YES } \\
(\%)\end{array}$ & $\begin{array}{c}\text { NO } \\
(\%)\end{array}$ \\
\hline $\begin{array}{l}\text { Specialists in the field of financial planning claim that when we receive any amount of } \\
\text { money the first payment must be made to our financial security, ie 10\% of the income } \\
\text { must be saved monthly. Do you think this habit is good for your peace of mind? }\end{array}$ & 96.8 & 3.2 \\
\hline Have you saved money so far? & 75.4 & 24.6 \\
\hline
\end{tabular}

Source: Authors' own contribution

In terms of the familiarity of this topic for respondents, $65.5 \%$ of them (Table 5) gave a grade of 5 (on a scale of 1 to 5 , where 1 means very low and 5 means very high), which means that the respondents are very familiar with the notion of saving.

TABLE 5. THE FAMILIARITY OF THE TOPIC

\begin{tabular}{|l|c|c|c|}
\hline \multicolumn{1}{|c|}{ Item } & Note & Frequency & Percent (\%) \\
\hline \multirow{2}{*}{$\begin{array}{l}\text { On a scale of 1 to 5, how familiar are you with the concept of } \\
\text { saving money? }\end{array}$} & 3 & 5 & 8.6 \\
\cline { 2 - 4 } & 5 & 15 & 25.9 \\
\hline
\end{tabular}

Source: Authors' own contribution

Regarding the saving behavior (Table 6), Romanians save, in principle, monthly, a variable amount (39.7\%), the second option of saving being represented by the existence of a cash surplus. The results of the study show that there may be people who may not save money so far.

TABLE 6. FREQUENCY AND AMOUNT SAVED

\begin{tabular}{|l|c|c|}
\hline \multicolumn{1}{|c|}{ Frequency and amount saved } & Frequency & Percent (\%) \\
\hline When I had a surplus & 16 & 27.6 \\
\hline Monthly, a variable amount & 23 & 39.7 \\
\hline Monthly, a fix amount & 12 & 20.7 \\
\hline Monthly, $10 \%$ of income & 6 & 10.3 \\
\hline I did not save money & 1 & 1.7 \\
\hline
\end{tabular}

Source: Authors' own contribution

According to the results obtained after processing the answers from the respondents, $98 \%$ of them would like to save $10 \%$ of their income per month. Regarding the amount that they want to save (monthly), the results can be seen in Table 7.

TABLE 7. THE AMOUNT TO BE SAVED PER MONTH

\begin{tabular}{|l|c|c|}
\hline \multicolumn{1}{|c|}{ Amount (LEI) } & Frequency & Percent (\%) \\
\hline $100-199$ & 21 & 36.2 \\
\hline $200-299$ & 16 & 27.6 \\
\hline $300-399$ & 5 & 8.6 \\
\hline $400-499$ & 5 & 8.6 \\
\hline More than 500 & 11 & 19.0 \\
\hline
\end{tabular}

Source: Authors' own contribution 
One of the objectives of the study was to identify the intention of Romanians to use the services of a financial advisor in the future for better management of funds. The results presented in Table 8 show that $77.6 \%$ of respondents would like to be guided by trusted people to choose the best saving solutions. When it comes to consulting a specialist in this field, people are more reluctant, only $44.8 \%$ would use his services, the remaining $55.2 \%$ would not be interested in taking part in a discussion with any financial consultants.

TABLE 8. INTEND TO WORK WITH A FINANCIAL ADVISOR IN THE FUTURE

\begin{tabular}{|l|c|c|}
\hline \multicolumn{1}{|c|}{ Items } & $\begin{array}{c}\text { YES } \\
(\%)\end{array}$ & $\begin{array}{c}\text { NO } \\
\text { (\%) }\end{array}$ \\
\hline $\begin{array}{l}\text { Would you like to have a trusted person by your side to guide you and offer you the } \\
\text { most profitable and safe solutions for saving? }\end{array}$ & 77.6 & 22.4 \\
\hline $\begin{array}{l}\text { Would you like to talk to an authorized planner about how you can achieve your } \\
\text { goals? }\end{array}$ & 44.8 & 55.2 \\
\hline
\end{tabular}

\section{Source: Authors' own contribution}

Regarding the saving period (table 9 ), it can be seen that most Romanians (67.2\%) save money for a period of maximum 15 months, but there are also cases where the saving period is significantly longer (11.4\% of respondents have been saving for more than 64 months).

TABLE 9. SAVING PERIOD

\begin{tabular}{|l|c|c|}
\hline \multicolumn{1}{|c|}{ Saving period (months) } & Frequency & Percent (\%) \\
\hline Less than 15 & 41 & 67.2 \\
\hline $16-31$ & 4 & 6.6 \\
\hline $32-47$ & 5 & 8.2 \\
\hline $48-63$ & 4 & 6.6 \\
\hline More than 64 & 7 & 11.4 \\
\hline
\end{tabular}

Source: Authors' own contribution

Regarding the amount saved (Table 10), it is observed that $91.9 \%$ of respondents save monthly, on average, less than 1000 Lei. It can be seen that there are also cases in which the amount increases significantly, the respondents saving amounts between 2000 and 4000 Lei.

TABLE 10. AVERAge AMOUNT SAVED PER MONTH

\begin{tabular}{|l|c|c|}
\hline \multicolumn{1}{|c|}{ Average amount saved per month (LEI) } & Frequency & Percent (\%) \\
\hline Less than 1000 & 57 & 91.9 \\
\hline $1001-2000$ & 3 & 4.8 \\
\hline $2001-3000$ & 1 & 1.6 \\
\hline $3001-4000$ & 1 & 1.6 \\
\hline
\end{tabular}

Source: Authors' own contribution 
Regarding the savings on which the respondents' answers are based (Table 11), it is concluded that they have quite high values, therefore, $77.4 \%$ have savings of at most $10000 \mathrm{LEI}$, but there are also cases in which the amounts saved, so far, exceed $30000 \mathrm{LEI}$.

TABLE 11. THE AVERAGE AMOUNT SAVED SO FAR

\begin{tabular}{|l|c|c|}
\hline $\begin{array}{c}\text { The average amount saved so } \\
\text { far (LEI) }\end{array}$ & Frequency & Percent (\%) \\
\hline Less than 10000 & 48 & 77.4 \\
\hline $10001-20000$ & 9 & 14.5 \\
\hline $20001-30000$ & 1 & 1.6 \\
\hline $30001-40000$ & 2 & 3.2 \\
\hline More than 40000 & 2 & 3.2 \\
\hline
\end{tabular}

Source: Authors' own contribution

Furthermore, the authors used Evans' guide (Evans, 1996) to study the Pearson's coefficients by analyzing the correlations between the variables mentioned in table 1. Pearson's coefficients were interpreted using the intervals declared by Evans as follows: [0-0.2) for very weak correlation; [0.2-0.4) for weak correlation; [0.4-0.6) for moderate correlation; [0.6-0.8) for strong correlation; [0.8-1) for very strong correlation, and 1 for perfect correlation. The correlations marked with "*" are statistically significant at a confidence level of $95 \%$, and those marked with "**" are statistically significant at a confidence level of $99 \%$.

In table 12 it can be seen the values of Pearson's coefficients for the analyzed variables. Based on these values, the following statements can be made: the more people consider that saving is a beneficial habit for them (OS1), the more they will be willing to save $10 \%$ of the monthly income (ISF1) $(R=0.701, p<0.01)$; The more respondents believe that the monthly income influences the saving (DP1), the more they will be willing to save a large amount of money (ISF2) $(R=-0.045, p>0.05)$; The longer the respondents consider a longer period to be beneficial for saving (SP1), the higher the average amount saved so far will be $(\mathrm{SP} 3)(\mathrm{R}=0.606, \mathrm{p}<0.01)$; As the value of the amount saved per month increases (SP2), so does the average total amount saved so far (SP3) $(R=0.525, p<0.01)$, but also increases the amount to be saved per month in future (ISF2) $(R=0.366, p<0.01)$. As the age of the respondents' increases (DP1), the registered income (DP4) also increases $(R=0.271, p<0.05)$. At the same time, the more respondents have jobs that are better rewarded (DP2), the higher the income level will be (DP4) $(R=-0.435, p<0.01)$, the amount to be saved per month increases (ISF2) $(R=$ $-0.234, p>0.05)$, but also increases the total amount saved (SP3) $(R=-0.212, p>0.05)$. 
Dinu A., Stanescu, M.M, Barbu, A.

YOUNG PEOPLE'S ATTITUDES AND FINANCIAL BEHAVIOUR. EVIDENCE FROM ROMANIA

TABLE 12. CORRELATIONS

\begin{tabular}{|l|l|l|l|l|l|l|l|l|l|l|l|}
\hline & OS1 & ISF1 & OS3 & DP4 & SP1 & SP2 & SP3 & ISF2 & DP1 & DP2 & DP3 \\
\hline OS1 & - & & & & & & & & & & \\
\hline ISF1 & $.701^{\star *}$ & - & & & & & & & & & \\
\hline OS3 & -.074 & .002 & - & & & & & & & & \\
\hline DP4 & .007 & .021 & -.006 & - & & & & & & & \\
\hline SP1 & .113 & .079 & $.316^{\star}$ & .1 & - & & & & & & \\
\hline SP2 & .048 & .034 & .151 & .221 & .221 & - & & & & & \\
\hline SP3 & .08 & .056 & .252 & .256 & $.606^{\star \star}$ & $.525^{\star \star}$ & - & & & & \\
\hline ISF2 & .128 & .001 & .129 & $.370^{\star \star}$ & .171 & $.366^{\star *}$ & $.377^{\star \star}$ & - & & & \\
\hline DP1 & -.092 & .087 & .038 & $.271^{\star}$ & .209 & .018 & .133 & -.045 & - & & \\
\hline DP2 & .074 & .045 & .071 & $-.435^{\star *}$ & -.039 & -.198 & -.212 & -.234 & $-.384^{\star \star}$ & - & \\
\hline DP3 & -.201 & -.141 & .049 & .137 & -.028 & -.04 & -.01 & .124 & -.077 & .141 & - \\
\hline
\end{tabular}

Source: Authors' own contribution

Note: * Correlation is significant at the 0.05 level (2-tailed); ${ }^{* *}$ Correlation is significant at the 0.01 level (2-tailed).

\section{CONCLUSIONS}

The need for this research was essentially related to the impact that saving power has on the economy. This study was also meant to analyse young people's intention to save money, both now and in the future.

The results of the study are more than gratifying, observing an increased interest in the trend of saving among young people from Romania. The existence and improvement of financial knowledge are key factors, which help the consumers cope with future economic changes. Also, more knowledge in the financial field has a positive impact on how consumers make decisions that can influence their wellbeing.

In addition to the desire and willingness to save money, people want to save money efficiently and safely, so they are willing to turn to specialized people in this field so that their financial resources are not wasted. The respondents of the study are willing to save monthly in order to build a solid financial base to use in case of emergency or maybe for a vacation so that they do not have to borrow.

At the moment, the world is constantly changing and decisions taken at the macroeconomic level have a significant impact on everyday life. Ensuring that the loved ones have everything they need to live a good life is the main goal for most of us. Therefore, when people have control over personal finances, it is easier for them to make efficient decisions. 
The results of this study must be carefully interpreted, this study is an exploratory one, which also has certain limitations. Firstly, this paper is a pilot study conducted on a small number of respondents (62 respondents). Secondly, the study analyzes the respondents' perceptions that can be influenced for example by their professions. Taking into account that the respondents of this study were students, employees in various fields and even entrepreneurs, the results of this paper could be different if the sample consisted of just one of these categories. Another limit of the study can be represented by the age of the respondents, this variable directly influencing the income of the respondents, therefore the total possible amount to be allocated to savings. Taking into account all these limits of the study, it is desired that in the future, a more extensive research will be carried out, on a much larger population on the Romanian territory to have a better overview of the saving phenomenon.

\section{REFERENCES}

Călin, M. (2018). Rata Dobânzii - Factor Determinant al Investiţiei în Instrumente De Economisire. Politici financiare și monetare în Uniunea Europeană, 32.

Cernea, S. (2012). Politica Monetară În Epoca Postcriză. Timişoara Journal of Economics, 5 (17): 5878.

Ciumara, T. (2013). Abordări locale ale educaţiei financiare. Analele Ştiinţifice ale Universităţii Cooperatist-Comerciale din Moldova, 2(12), 340-344.

Constantin, D. L. (2012). Economie si Politici Regionale. Economie teoretica si aplicata, XIX(6).

Dăianu, D. (2020). Ratele reale negative persistă - încotro se merge?. Retrieved January 10, 2020, from https://www.bursa.ro/daniel-daianu-consilier-al-guvernatorului-bnr-ratele-reale- negative-persistaincotro-se-merge-05257830 .

EUROSTAT. (2018). Main GDP aggregates per capita. Retrieved April 2, 2020, from https://appsso.eurostat.ec.europa.eu/nui/show.do?dataset=nama_10_pc\&lang=en (accessed 04 2020).

Evans, J., (1996). Straightforward statistics for the behavioral sciences. Pacific Grove, Issue ISBN-13: 978-0534231002.

Fornell, C. \& Larcker, D. F. (1981). Evaluating Structural Equation Models with Unobservable Variables and Measurement Error. Journal of Marketing Research. 18(1): 39-50.

Goodhart, C. (1984). The Importance of Money. In: Monetary Theory and Practice. London.

Hair, J. F. J., Money, A. H., Samouel, P. \& Page, M. (2007). Research Methods for Business. John Wiley \& Sons.

Intrum. (2019). "European Consumer Payment Report 2019". Retrieved January 10, 2020, from https://www.intrum.ro/media/6969/raportul-european-al-platilor- consumatorilor-2019-intrumromania.pdf.

Traut-Mattausch, E., \& Jonas, E. (2011). Why do people save? The influence of financial satisfaction and income on saving. Journal of Psychology. 219(4): 246-252. 